\title{
PENGARUH KECERDASAN EMOSIONAL DAN MINAT BELAJAR TERHADAP HASIL BELAJAR BIOLOGI SISWA KELAS X MIPA DI SMAN RAMBIPUJI JEMBER
}

\author{
Novia Miftahul Janah ${ }^{1}$, Umi farihah ${ }^{2}$ \\ ${ }^{1}$ Universitas Islam Negeri Kiai Haji Achamd Siddiq Jember, Jl. Mataram No. 1 \\ Mangli, Jember 68136, Jawa Timur, Indonesia \\ E-mail: mittaaa09@gmail.com
}

DOI : 10.35719/alveoli.v2i2.54

\begin{abstract}
This research is motivated by students as components that have the responsibility to improve the quality of education. Positive changes in student behavior which are the result of the learning process at school can be seen from their result of learning. Student learning results can be seen from the cognitive, affective and psychomotor factors of students wherein learning is not only mastery the theory concepts of subject, but also mastery of habits, perceptions, pleasures, interests and talents, social adjustment, skills, goals, desires and expectations. One of the psychological factors that influence learning results that are considered the most essential are intelligence, and interest. This study were aimed to determine the effect of emotional intelligence and interest in learning simultaneously and partially on the biology learning results of class X MIPA students at SMAN RambiPuji Jember. This study was used a quantitative approach with the type of associative research conducted at SMAN RambiPuji Jember. The population includes all students of class X, 143 students were taken. Determination of the number of sample were used the Slovin formula obtained 105 students, using the cluster random sampling technique, three classes were taken, totaling 107 students. Data collection techniques were used questionnaires and documentation and data analysis were used multiple linear regression analysis. The results showed that there was a simultaneous and partial influence of emotional intelligence and interest in learning on the biology learning outcomes of students of class X MIPA at SMAN Rambi Puji Jember.
\end{abstract}

Keywords: emotional intelligence, interest in learning, learning outcomes

\begin{abstract}
Abstrak: Penelitian ini dilatarbelakangi oleh siswa sebagai komponen yang mempunyai tanggung jawab untuk meningkatakan kualitas pendidikan. Perubahan positif perilaku siswa yang merupakan hasil dari proses belajar di sekolah dapat dilihat dari hasil belajarnya. Hasil belajar siswa dapat dilihat dari aspek kognitif, afektif dan psikomotorik siswa karena belajar tidak hanya penguasaan konsep teori mata pelajaran saja, tetapi juga penguasaan kebiasaan, persepsi, kesenangan, minat-bakat, penyesuaian sosial, keterampilan, cita-cita, keinginan dan harapan. Salah satu faktor psikologis yang mempengaruhi hasil belajar yang dipandang paling esensial adalah kecerdasan, dan minat. Penelitian ini bertujuan untuk mengetahui pengaruh kecerdasan emosional dan minat belajar secara simultan dan parsial terhadap hasil belajar biologi siswa kelas X MIPA di SMAN Rambipuji Jember. Penelitian ini menggunakan pendekatan kuantitatif dengan jenis penelitian asosiatif yang dilakukan di SMAN Rambipuji Jember. Populasi meliputi seluruh siswa kelas X yang berjumlah 143 siswa. Penentuan jumlah sampel menggunakan rumus slovin yang didapat 105 siswa, dengan menggunakan teknik cluter random sampling maka diambil sebanyak tiga kelas yang berjumlah 107 siswa. Teknik pengumpulan data menggunakan angket dan dokumentasi serta analisis data menggunakan analisis regresi linier berganda. Hasil penelitian menunjukkan bahwa terdapat pengaruh kecerdasan emosional dan minat belajar secara simultan dan parsial terhadap hasil belajar biologi siswa kelas X MIPA di SMAN Rambipuji Jember.
\end{abstract}

Kata kunci: kecerdasan emosional, minat belajar, hasil belajar 
Pendidikan merupakan suatu usaha untuk menumbuh kembangkan potensi manusia dengan mendorong dan menyediakan kegiatan belajar mengajar agar tercapai kemajuan manusia yang cerdas dan berkualitas (Siregar, 2019: 81). Salah satu tingkat pendidikan bagi siswa untuk melakukan kegiatan belajar adalah pendidikan menengah. Pendidikan menengah dilaksanakan melanjutkan dan memperluas pengetahuan yang diperoleh dari sekolah dasar dan menengah pertama, serta mempersiapkan peserta didik menjadi bagian dari masyarakat yang mampu melakukan timbal balik dengan sosial, budaya, dan alam sekitar serta dapat mengembangkan kemampuan untuk bekerja atau melanjutkan ke perguruan tinggi. Sekolah Menengah Atas (SMA) adalah salah satu pendidikan menengah yang betujuan untuk mempersiapkan ke perguruan tinggi atau bekerja (Berutu, 2018: 108).

Sebagai komponen pendidikan siswa mempunyai tanggung jawab untuk meningkatakan kualitas pendidikan (Sulastyaningrum, 2019: 3). Siswa yang menempuh pendidikan diharapkan memiliki perubahan positif dalam dirinya,seperti tujuan pendidikaan nasional yaitu melahirkan generasi muda yang memiliki pengetahuan luas dan berkepribadiaan baik. Perubahan positif perilaku siswa yang merupakan hasil dari proses belajar disekolah dapat dilihat dari hasil belajarnya (Sari, 2019: 40).

Secara umum hasil belajar adalah adanya perubahan kemampuan pengetahuan, sikap, keterampilan, dan perilaku siswa setelah kegiatan belajar akibat dari sebuah pengalaman. (Ilmiyah, 2019: 46). Tercapainya dan suksesnya sebuah proses pembelajaran dapat dilihat dari hasil belajar siswa. Suksesnya proses belajar siswa dapat dilihat dari tinggi dan bagus nilai hasil belajar. Namun jika hasil belajar siswa rendah maka proses pembelajaran menunjukan tidak tercapainya proses pembelajaran dengan sukses (Saputra, 2018: 25).

Hasil belajar dapat dilihat dari segi kognitif, afektif, dan psikomotorik siswa karena belajar tidak hanya penguasan konsep teori mata pelajaran saja, tetapi juga penguasaan kebiasaan, persepsi, kesenangan, minat-bakat, penyusaian sosial, keterampilan, cita-cita, keinginan dan harapan ( Zikra, 2016: 94). Faktor psikologis yang mempengaruhi hasil belajar yang dipandang paling essensial adalah, kecerdasan, emosi, motivasi bakat, dan minat (Sari, 2020: 40).

Kecerdasan yang dimiliki manusia tidak hanya satu sisi saja, namun banyak kecerdasan yang berfungsi untuk meningkatkan kualitas hidupnya. Setidaknya terdapat sembilan kecerdasan yang dimiliki manusia yaitu kecerdasan linguistik, kecerdasan matematis-logis, kecerdasan ruang visual (spasial), kecerdasan kinestik, kecerdasan musikal, kecerdasan 
naturalis, kecerdasan eksistensial, kecerdasan intrapersonal, dan kecerdasan interpersonal (Indria, 2020: 29).

Setiap siswa tentu memiliki kecenderungan kecerdasan yang paling dominan, namun dengan adanya perkembangan pola pikir pembelajaran sekarang ini, dari belajar secara individu menjadi berbasis kelompok, sehingga kecerdasan interpersonal menjadi penting untuk dimiliki dan dikembangkan oleh siswa (Salsabila, 2020: 36). Kecerdasan interpersonal adalah kemampuan yang dimiliki seseorang untuk menjalin hubungan dengan orang-orang disekitarnya. Jika seseorang memiliki kecerdasan interpersonal yang baik, maka individu dapat menjalin hubungan yang baik dengan orang lainnya. Seseorang yang memiliki kecerdasan interpersonal tinggi akan mampu membina hubungan dengan orang lain melalui kemampuan dalam berinteraksi sehingga seseorang itu mampu memecahkan masalah yang nantinya akan dihadapi (Qowiyah, 2020: 97). Kecerdasan emosional merupakan salah satu bagian dalam kecerdan interpersonal, sebagai bentuk dari kemampuan untuk memonitor atau mengetahui persaaan diri sendiri, dan dapat membedakan tentang emosi yang dimilikinya, serta dapat menjadikan emosi yang dimiliki tersebut untuk menjadi panduan dalam bertindak, berfikir, bertingkah laku, dan bertutur kata dalam kehidupan sosial.

Menurut Indriawati (2018: 1) Kemampuan dalam memahami dan merasakan secara efektif terhadap kemampuan dalam memotivasi diri, pengendalian diri, memahami perasaan yang lain dengan bentuk perilaku mengontrol emosi ketika mengambil keputusan merupakan kecerdasan emosional. (Darmayanti, 2021: 17).

Dalam mencapai prestasi yang baik, tidak hanya diperlukan kecerdasan, melainkan juga minat belajar yang tumbuh dari dalam diri siswa. tanpa adanya minat, siswa tidak akan mempunyai hasrat untuk melakukan kegiatan belajar. Dan jika siswa mempunyai minat pada suatu pelajaran, maka siswa akan terdorong untuk aktif dalam kegiatan pembelajaran pada mata pelajaran tersebut. Hasrat seseorang untuk memenuhi kesediaannya belajar dapat diukur melalui kesukacitaan, ketertarikan, perhatian, dan keterlibatan. Besar kecilnya minat sangat bergantung pada penerimaan suatu hubungan antara diri sendiri dengan sesuatu yang ada disekitarnya. Minat siswa dapat diketahui melalui suatu pernyataan yang menunjukan siswa lebih menyukai suatu hal dari pada hal lainnya. Wujud minat juga dapat dilihat dari peran siswa dalam melakukan aktivitas. Siswa yang berminat terhadap sesuatu maka siswa cenderung memberikan perhatian yang lebih besar terhadap sesuatu tersebut (Nesi, 2018: 81). 
Proses belajar dikatakan efektif jika terdapat interaksi antara guru dan siswa, sehingga minat belajar siswa dalam proses pembelajaran sangat dibutuhkan. Minat dapat diartikan sebagai kecenderungan individu dalam keterlibatan secara terus-menerus maupun perhatian yang berpusat pada objek yang diterapkan oleh suatu interaksi khusus diantara individu serta objek yang dibuat melalui hubungannya dengan lingkungan. Minat belajar juga diartikan suatu yang membangkitkan motivasi bedasarkan kemauan dan kenyamanan siswa dalam keterlibatan pada kewajiban atau kemauan untuk mendapat wawasan (Rohimah, 2019: 1229)

Biologi merupakan pelajaran yang mengkaji mengenai mahluk hidup dan komponen penyusun kehidupan. Pendidikan biologi harus bisa mengkomunikasikan pengetahuannya, mengajak siswa aktif dan kreatif dalam proses pembelajaran dan dapat berinteraksi dengan siswa lainnya, agar tujuan pembelajaran tercapai (Puspita, 2018: 2).

SMAN Rambipuji Jember merupakan sekolah menengah atas yang menjadi Rintisan Sekolah Standar Nasional yang berada di pinggir kota, yang mempunyai dua jurusan IPS dan MIPA yang dimasing-masing jurusan mempunyai empat kelas untuk kelas X, XI, dan XII. Namun dalam proses pembelajaran daring hanya terbatas menggunakan aplikasi google classroom, sehingga interaksi antara guru dan siswa kurang terjalin. Bedasarkan hasil observasi dan wawancara kepada guru biologi kelas X MIPA di SMAN Rambipuji Jember mengatakan bahwa meskipun pembelajaran hanya sebatas menggunakan google Classroom namun masih banyak siswa yang mendapat nilai diatas Kriteria Ketuntasan Minimal (KKM). Hal ini terkait adanya faktor yang mempengaruhi hasil belajar siswa.

Bedasarkan hasil observasi dan wawancara kepada guru di SMAN Rambipuji Jember, bahwa beberapa siswa memiliki hubungan pertemanan yang kurang interaktif, bahkan siswa ada yang belum mengenal teman sekelasnya hal ini disebabkan siswa tidak pernah melakukan pembelajaran secara langsung di dalam kelas dikarenakan pandemi Covid-19. Terkait dengan pengelolaan emosi yang ada di dalam diri siswa, pengelolaan emosi siswa kurang stabil ketika nilai biologi yang didapat kurang memuaskan, siswa merasa kecewa dan terkadang timbul rasa marah pada diri siswa. Melalui kegiatan online dalam bentuk pembelajaran daring mengakibatkan guru tidak dapat mengontrol dan memantau kegiatan siswa. Kemudian untuk minat belajar siswa kelas X MIPA di SMAN Rambipuji Jember, dalam proses pembelajaran di google classroom siswa yang aktif biasanya akan cepat tanggap terhadap materi dan ketika siswa diberi tugas oleh guru maka akan segera dikerjakan, berbeda dengan siswa yang pasif dalam pembelajaran, jika guru memberikan tugas biasanya siswa tidak langsung mengerjakan 
bahkan ada bebarapa siswa harus dihubungi satu persatu melalui whatsapp agar siswa mau mengerjakan tugas yang diberikan. Dengan ini peneliti menduga ada pengaruh kecerdasan emosioanl dan minat belajar terhadap hasil belajar biologi. Dalam hal tersebut peneliti tertarik untuk melakukan penelitian dengan Judul "Pengaruh Kecerdasan Emosional dan Minat Belajar terhadap Hasil Belajar Biologi Siswa Kelas X MIPA di SMAN Rambipuji Jember”.

\section{METODE}

Dalam penelitian ini pendekatan yang digunakan adalah pendekatan kuantitatif karena data-data dalam penelitian berupa angka- angka. penelitian kuantitatif adalah penelitian yang banyak menuntut penggunaan angka, mulai dari pengumpulan data, penafsiran terhadap data tersebut, serta penampilan dari hasilnya. Demikian pula pada tahap kesimpulan penelitian akan lebih baik bila disertai dengan gambar, table, grafik, atau tampilan lainnya (Siyoto, 2015: 38).

Jenis penelitian yang digunakan dalam penelitian ini yaitu penelitian asosiatif kausal. Jenis penelitian asosiatif adalah penelitian yang bersifat menyatakan hubungan antara dua variabel atau lebih. Terdapat tiga hubungan yaitu: hubungan simetris, hubungan kausal, dan hubungan interaktif/resiprokal/timbal balik. Pada penelitian ini lebih ke hubungan kausal. Hubungan kausal adalah hubungan yang bersifat sebab akibat antar dua variabel atau lebih. Dengan penelitian ini, maka akan dapat dibangun suatu teori yang dapat berfungsi untuk menjelaskan, meramalkan dan mengontrol suatu gejala Syofian (2013: 7). Jadi disini ada variabel independen (variabel yang mempengaruhi) dan dependen (dipengaruhi) (Sugiyono,2018:61-62).

Dalam penelitian ini menggunakan metode penelitian survey. Metode penelitian survey adalah penelitian dengan tidak melakukan perubahan (tidak ada perlakuan khusus) terhadap variabel-variabel yang diteliti (Siregar, 2013:4). Pada penelitian ini peneliti berusaha untuk menemukan suatu pengaruh antara kecerdasan emosional dan minat belajar terhadap hasil belajar biologi siswa kelas X MIPA di SMAN Rambipuji Jember. Variabel penelitian ini adalah kecerdasan emosional, minat belajar, dan hasil belajar.

Pada penelitian ini populasi yang digunakan adalah seluruh siswa kelas X MIPA di SMAN Rambipuji Jember yang berjumlah 143 siswa. Dan untuk mengetahui jumlah sampel yang akan diteliti, peneliti mengunakan rumus Slovin. dari perhitungan tersebut dapat diketahui jumlah sampel yang menggunakan rumus Slovin adalah 105. Peneliti menetukan jumlah sampel dalam penelitian ini sebanyak 107 siswa. 
Penelitian ini menggunakan bentuk instrumen utama dengan angket dan kuisioner untuk memperoleh data. Kuesioner atau angket dalam penelitian ini digunakan sebagai instrumen utama, untuk mendapatkan data tentang kecerdasan emosional dan minat belajar siswa kelas X MIPA di SMAN Rambipuji Jember. Dalam penelitian ini, data yang diperoleh dari dokumentasi adalah data dari hasil belajar siswa kelas X MIPA di SMAN Rambipuji Jember yang berupa nilai hasil Penelian Tengah Semester (PTS) genap mata pelajaran biologi tahun pelajaran 2020/2021.

Ada dua teknik analisis data yang digunakan yaitu analisis deskriptif dan analisis inferensial. Sebelum dilakukan analisis regresi linier berganda, terlebih dahulu dilakukan uji prasyarat terhadap hasil penelitian yaitu, uji normalitas, uji kolineritas, uji heteroskedastisitas, dan uji autokorelasi. Kemudian untuk uji hipotesis mengunakan teknik analisis korelasi multivariat dengan model analisis regresi linier berganda dan teknik analisis korelasi bivariet dengan model analisis regresi linier sederhana.

\section{HASIL}

1. Analisis Deskriptif

Dari hasil masing-masing variabel yaitu kecerdasan emosional $\left(\mathrm{X}_{1}\right)$, minat belajar $\left(\mathrm{X}_{2}\right)$, dan hasil belajar $(\mathrm{Y})$ akan disajikan dalam bentuk analisis deskriptif berikut ini.

a. Kecerdasan emosional siswa kelas X MIPA SMAN Rambipuji Jember

Berikut ini adalah hasil pengelolahan menggunakan progam Software SPSS v.17.

Tabel 1. Deskripsi Kategori Kecerdasan Emosional

\begin{tabular}{ccccc} 
No. & $\begin{array}{c}\text { Tingkat pencapaian } \\
\text { skor }\end{array}$ & Frekuensi & Persentase & Kategori \\
\hline 1. & $104-123$ & 12 & $11 \%$ & Sangat tinggi \\
\hline 2. & $84-103$ & 79 & $74 \%$ & Tinggi \\
\hline 3. & $64-83$ & 16 & $15 \%$ & Sedang \\
\hline 4. & $44-63$ & 0 & 0 & Rendah \\
\hline 5. & $24-43$ & 0 & 0 & Sangat rendah \\
\hline & Total & $\mathbf{1 0 7}$ & $\mathbf{1 0 0 \%}$ & \\
\hline
\end{tabular}

Beikut ini adalah hasil presentase kecerdasan emosional yang ditunjukan dengan diagram lingkaran. 


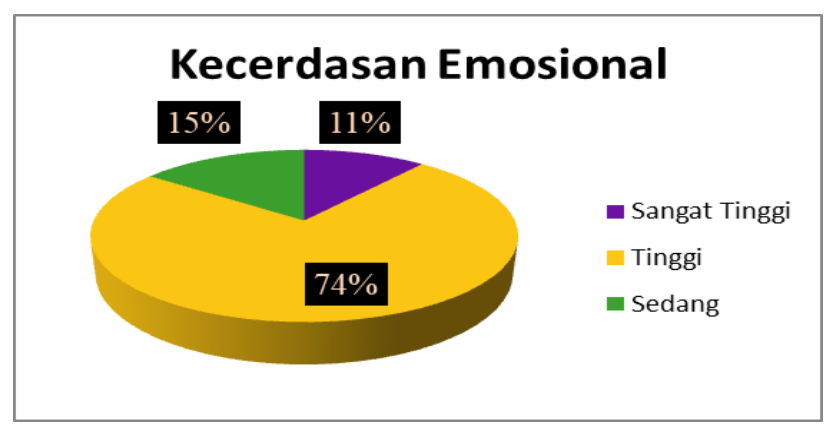

\section{Gambar 1. Kecerdasan Emosional}

Bedasarkan data tersebut, diketahui bahwa kecerdasan emosional siswa kelas $\mathrm{X}$ MIPA di SMAN Rambipuji Jember tergolong baik, karena dari 107 siswa menyatakan terdapat 12 siswa dengan kategori sangat tinggi (11\%), 79 siswa dengan kategori tinggi (74\%), dan 16 siswa dengan kategori sedang (15\%).

b. Minat belajar siswa kelas X MIPA SMAN Rambipuji Jember

Berikut ini adalah hasil pengelolahan menggunkan progam Software SPSS v.17.

\section{Tabel 2. Deskripsi Kategori Minat Belajar}

\begin{tabular}{ccccc}
\hline No & $\begin{array}{c}\text { Tingkat pencapaian } \\
\text { skor }\end{array}$ & Frekuensi & Persentase & Kategori \\
\hline 1. & $114-135$ & 7 & $7 \%$ & Sangat inggi \\
\hline 2. & $92-113$ & 54 & $50 \%$ & Tinggi \\
\hline 3. & $70-91$ & 46 & $43 \%$ & Sedang \\
\hline 4. & $48-69$ & 0 & 0 & Rendah \\
\hline 5. & $26-47$ & 0 & 0 & Sangat rendah \\
\hline & Jumlah & $\mathbf{1 0 7}$ & $\mathbf{1 0 0 \%}$ & \\
\hline
\end{tabular}

Beikut ini adalah hasil presentase minat belajar yang ditunjukan dengan diagram lingkaran

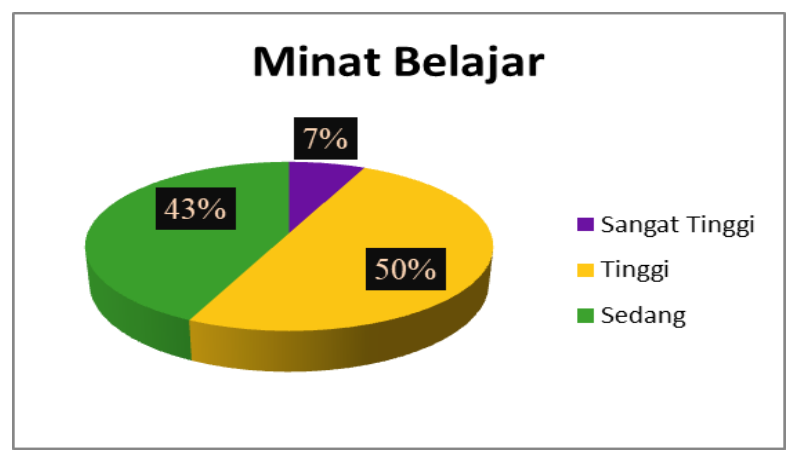

\section{Gambar 2. Minat Belajar}

Bedasarkan data tersebut, diketahui bahwa minat belajar siswa kelas X MIPA di SMAN Rambipuji Jember tergolong baik, karena dari 107 siswa menyatakan terdapat 
7 siswa dengan kategori sangat tinggi (7\%), 54 siswa dengan kategori tinggi (50\%), dan 46 siswa dengan kategori sedang (43\%).

c. Hasil belajar siswa kelas X MIPA SMAN Rambipuji Jember

Berikut ini adalah hasil pengelolahan menggunkan progam Software SPSS v.17.

Tabel 3. Deskripsi Kategori Hasil Belajar

\begin{tabular}{ccccc} 
No. & $\begin{array}{c}\text { Tingkat pencapaian } \\
\text { skor }\end{array}$ & Frekuensi & Persentase & Kategori \\
\hline 1. & $80-100$ & 84 & $79 \%$ & Sangat tinggi \\
\hline 2. & $60-79$ & 23 & $21 \%$ & Tinggi \\
\hline 3. & $40-59$ & 0 & 0 & Sedang \\
\hline 4. & $20-39$ & 0 & 0 & Rendah \\
\hline 5. & $0-19$ & 0 & 0 & Sangat rendah \\
\hline & Total & $\mathbf{1 0 7}$ & $\mathbf{1 0 0 \%}$ & \\
\hline
\end{tabular}

Beikut ini adalah hasil presentase hasil belajar yang ditunjukan dengan diagram lingkaran.

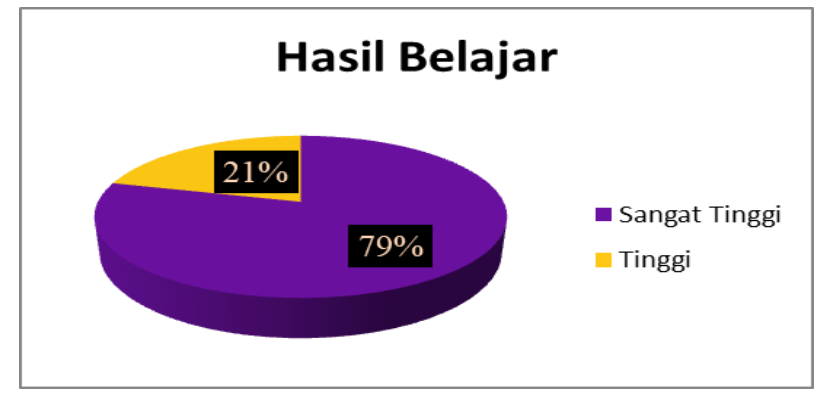

\section{Gambar 3. Hasil Belajar}

Bedasarkan data tersebut, diketahui bahwa hasil belajar siswa kelas X MIPA di SMAN Rambipuji Jember tergolong sangat baik, karena dari 107 siswa menyatakan terdapat 84 siswa dengan kategori sangat tinggi (79\%), 23 siswa dengan kategori tinggi (21\%).

2. Analisis Inferensial

a. Uji Prasyarat

Sebelum dilakukan dilakukan analisis regresi, terlebih dahulu dilakukan uji prasyarat terhadap hasil penelitian sebagai berikut.

1) Uji Normalitas:

Model regresi memenuhi kenormalan apabila data menyebar disekitar garis diagonal dan mengikuti arah garis diagonal. 
Dalam uji normalitas penguji menggunakan bantuan Software SPSS v.17 dan didapat hasil sebagai berikut.

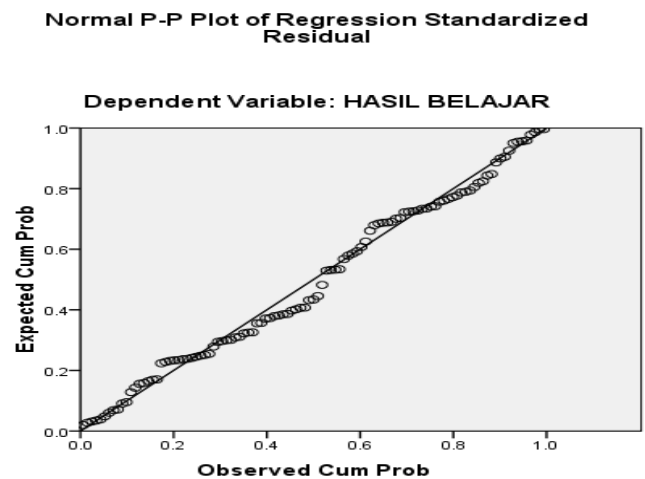

\section{Gambar 4. Uji Normalitas Kecerdasan Emosional dan Minat Belajar terhadap Hasil belajar}

Bedasarkan gambar 4 yang diperoleh dari Normal P-P Plot of Regression Standardized Residual menyatakan bahwa data berdistribusi normal karena data menyebar disekitar garis diagonal dan mengikuti arah garis diagonal. Sehingga persyaratan normalitas dikatakan sudah terpenuhi.

2) Uji Kolineritas

Uji kolineritas digunakan untuk melihat apakah terjadi korelasi yang kuat antara variabel independen penelitian atau tidak. Pedoman keputusan bedasarkan nilai VIF yaitu jika VIF $<2$ dan nilai Tolerance $>0,2$. Maka artinya tidak terjadi kolineritas dalam model regresi.

Dalam uji kolineritas meggunakan bantuan Software SPSS v.17 dan didapat hasil sebagai berikut.

\section{Tabel 4. Uji Kolineritas}

\begin{tabular}{cc}
\hline \multicolumn{2}{c}{ Collinerity Statistics } \\
\hline Tolerance & VIF \\
\hline .529 & 1.892 \\
.529 & 1.892 \\
\hline
\end{tabular}

Bedasarkan tabel 4, nilai dari kedua variabel yaitu $\mathrm{VIF}<2$ dan nilai tolerance $>0,2$. Maka bedasarkan pedoman keputusan tidak terjadi kolineritas dalam model regresi.

3) Uji Heteroskedastisitas

Uji heteroskedastisitas digunakan untuk menguji apakah suatu keadaan dalam pengamatan dimana semua gangguan mempunyai variasi yang sama atau tidak. 
Jika titik-titik dalam plot yang terbentuk menyebar secara acak dan tidak menunjukkan suatu pola tertentu maka dikatakan model regresi terbebas dari hetroskedastisitas.

Dalam uji heteroskedastisitas meggunakan bantuan Software SPSS v.17 dan didapat hasil sebagai berikut.

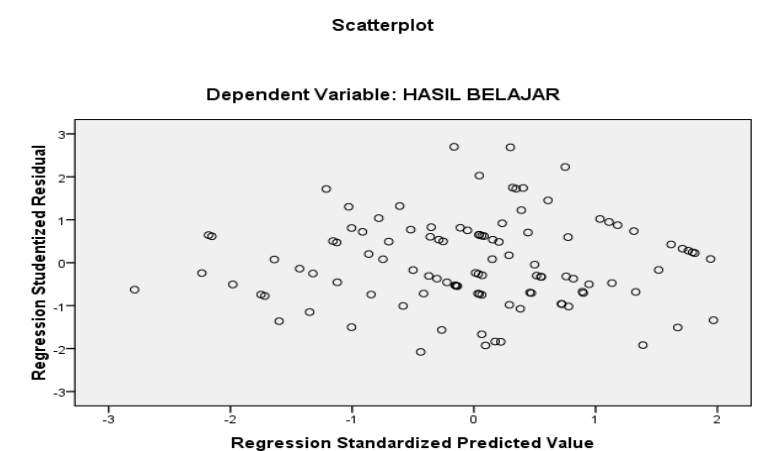

Gambar 5.Uji Heteroskedastisistas

Bedasarkan Gambar 5, menyatakan bahwa titik-titik dalam plot yang terbentuk menyebar secara acak dan tidak menunjukkan suatu pola. Sehingga persyaratan heteroskedastisitas dikatakan sudah terpenuhi.

4) Uji Autokorelasi

Uji autokorelasi digunakan untuk mendeteksi apakah data random atau tidak dan juga untuk mengidentifikasi suatu model seri waktu yang sesuai. Untuk melihat analisis regresi terbebas dari autokorelasi maka bisa dilihat dari nilai koefesien $1,65<\mathrm{DW}<2,35$.

Dalam uji autokorelasi meggunakan bantuan Software SPSS v.17 dan didapat hasil sebagai berikut.

Tabel 5. Uji Autokorelasi

\begin{tabular}{|c|c|c|c|c|c|}
\hline \multicolumn{6}{|c|}{ Model Summary } \\
\hline Model & $\mathrm{R}$ & R Square & $\begin{array}{l}\text { Adjusted R } \\
\text { Square }\end{array}$ & $\begin{array}{l}\text { Std. Error of the } \\
\text { Estimate }\end{array}$ & Durbin-Watson \\
\hline 1 & $.716^{\mathrm{a}}$ & .513 & .503 & 4.38007 & 1.778 \\
\hline \multicolumn{6}{|c|}{ a. Predictors: (Constant), MINAT BELJAR, KECERDASAN EMOSIONAL } \\
\hline
\end{tabular}

Berdasarkan tabel 5, bahwa angka Durbin Waston $1,65<1,778<2,35$. Yang menyatakan nilai koefesien dapat dikatakan tidak terdapat masalah atau autokorelasi. 
b. Pengujian Hipotesis

Pengajuan hipotesis pada penelitian ini menggunakan analisis regresi linier berganda yaitu untuk menguji hipotesis yang diajukan.

$\mathrm{H}_{\mathrm{a}} 1$ : Terdapat pengaruh yang signifikan kecerdasan emosional dan minat belajar secara simultan terhadap hasil belajar biologi siswa kelas X MIPA di SMAN Rambipuji Jember.

$\mathrm{H}_{0} 1$ : Tidak terdapat pengaruh yang signifikan kecerdasan emosional dan minat belajar secara simultan terhadap hasil belajar biologi siswa kelas X MIPA di SMAN Rambipuji Jember.

$\mathrm{H}_{\mathrm{a}} 2$ : Terdapat pengaruh yang signifikan kecerdasan emosional dan minat belajar secara parsial terhadap hasil belajar biologi siswa kelas X MIPA di SMAN Rambipuji Jember.

$\mathrm{H}_{0} 2$ : Tidak terdapat pengaruh yang signifikan kecerdasan emosional dan minat belajar secara parsial terhadap hasil belajar biologi siswa kelas X MIPA di SMAN Rambipuji Jember.

Untuk mengetahui hasil rekapitulasi regresi linier berganda pengaruh kecerdasan emosional dan minat belajar terhadap hasil belajar biologi siswa, peneliti meggunakan bantuan Software SPSS v.17 dan didapat hasil sebagai berikut.

Tabel 6. Rekapitulasi Hasil Koefesien Berganda

\begin{tabular}{lccccccc}
\hline $\begin{array}{c}\text { Variabel } \\
\text { Bebas }\end{array}$ & $\begin{array}{c}\text { Variabel } \\
\text { Terikat }\end{array}$ & $\begin{array}{c}\text { Koefisien } \\
\text { regresi b }\end{array}$ & t hitung & t table & Sig. & $\mathbf{r}^{2}$ & $\begin{array}{c}\text { Keputusan } \\
\left(\mathbf{H}_{\mathbf{a}} \mathbf{2}\right)\end{array}$ \\
\hline $\begin{array}{l}\text { Kecerdasan } \\
\text { Emosional }\end{array}$ & $\begin{array}{c}\text { Hasil } \\
\text { Belajar }\end{array}$ & 0,384 & 5,803 & 1,983 & 0,000 & 0,487 & Diterima \\
\hline $\begin{array}{l}\text { Minat } \\
\text { Belajar }\end{array}$ & Hasil & 0,122 & 2,345 & 1,983 & 0,021 & 0,355 & Diterima \\
\hline Kelajar & & & & & & & \\
F hitung $=54,722$ & & & & & & \\
F tabel $=3,08$ & & & & & & \\
Sig F $=0,00$ \\
$\begin{array}{l}\text { R Square }=0,513 \\
\alpha=0,05\end{array}$
\end{tabular}

Untuk mengetahui pengaruh variabel bebas secara simultan terhadap variabel terikat digunakan uji statistik F. Dengan menggunakan tingkat signifikan 5\%. Dalam pengujian uji statistik $\mathrm{F}$ digunakan untuk menguji rumusan masalah nomor empat. Adapun hasil uji statistik F dapat dilihat pada tabel 6. 
Bedasarkan analisis data pada tabel 6, diperoleh nilai $F_{\text {hitung }}>F_{\text {tabel }}(54,722>$ $3,08)$ dengan sig $=0.000$. karena nilai sig $0.000<0.05$ maka dapat dikatakan kecerdasan emosional dan minat belajar secara bersama-sama (simultan) berpengaruh positif dan signifikan terhadap hasil belajar siswa. Sehingga alternatif $1\left(\mathrm{H}_{\mathrm{a}} 1\right)$ yaitu "Terdapat pengaruh yang signifikan kecerdasan emosional dan minat belajar secara simultan terhadap hasil belajar biologi siswa kelas X MIPA di SMAN Rambipuji Jember" diterima.

Hasil tabel 6, tersebut juga menjawab hipotesis alternatif $2\left(\mathrm{H}_{a} 2\right)$. Dengan uji statistik $\mathrm{t}$ dapat diketahui apakah ada pengaruh kecerdasan emosional dan minat belajar secara parsial terhadap hasil belajar biologi kelas X MIPA di SMAN Rambipuji Jember. Penjelasan hasil uji t sebagai berikut:

a. Bedasarkan pada tabel 6 diperoleh nilai $t_{\text {hitung }}>t_{\text {tabel }}(5,803>1983)$ dengan sig $=0.000$. karena nilai sig $0.00<0.05$ maka dapat dikatakan signifikan, hal ini menunjukan hipotesis alternatif $2\left(\mathrm{H}_{a} 2\right)$ diterima yang artinya ada pengaruh yang positif dan signifikan kecerdasan emosional secara parsial terhadap hasil belajar siswa kelas X MIPA di SMAN Rambipuji Jember.

b. Bedasar pada tabel 6 diperoleh nilai $t_{\text {hitung }}>t_{\text {tabel }}(2,345>1,983)$ dengan sig $=$ 0.05. karena nilai sig $0.021<0.05$ maka dapat dikatakan signifikan, hal ini menunjukan hipotesis alternatif $2\left(\mathrm{H}_{a} 2\right)$ diterima yang artinya ada pengaruh yang positif dan signifikan antara minat belajar secara pasrsial terhadap hasil belajar siswa kelas X MIPA di SMAN Rambipuji Jember.

Dari hasil uji signifikan secara simultan dan parsial memberikan nilai yang baik. Dari hasil data uji signifikan secara keseluruhan (uji F) disimpulkan bahwa kecerdasan emosional dan minat belajar secara simultan berpengaruh signifikan terhadap hasil belajar siswa kelas X MIPA di SMAN Rambipuji Jember. Kemudian data hasil uji signifikan secara parsial (uji t) disimpulkan bahwa kecerdasan emosional dan minat belajar sacara parsial berpengaruh terhadap hasil beljar siswa kelas X MIPA di SMAN Rambipuji Jember. Untuk hasil estimasi kecerdasan emosional dan minat belajar dapat dinyatakan sebagai berikut:

$$
Y=36,138+0,384\left(X_{1}\right)+0,122\left(X_{2}\right)
$$

Nilai koefisien regresi untuk variabel kecerdasan emosional $\left(\mathrm{X}_{1}\right)$ adalah 0,384. Dapat diartikan bahwa variabel kecerdasan emosional $\left(\mathrm{X}_{1}\right)$ berubah sebesar satu 
satuan maka variabel hasil belajar (Y) akan berubah sebesar 0,384 satuan dengan asumsi variabel bebas lainnya tetap maka jika input kecerdasan emosional ditambah satu nilai maka akan menaikan hasil belajar biologi siswa kelas X MIPA di SMAN Rambipuji Jember sebesar 38,4\%. Kemudian untuk koefesien determinasi $\left(\mathrm{r}^{2}\right)$ variabel kecerdasan emosional $\left(\mathrm{X}_{1}\right)$ yaitu 0,487 yang artinya sumbangan variabel $\left(\mathrm{X}_{1}\right)$ terhadap naik turunya variabel (Y) sebesar 48,7\% dimana variabel bebas lainnya tetap.

Nilai koefisien regresi untuk variabel minat belajar $\left(\mathrm{X}_{2}\right)$ adalah 0,122 . Dapat diartikan bahwa variabel minat belajar $\left(\mathrm{X}_{2}\right)$ berubah sebesar satu satuan maka variabel hasil belajar (Y) akan berubah sebesar 0,122 satuan dengan asumsi variabel bebas lainnya tetap maka jika input kecerdasan emosional ditambah satu nilai maka akan menaikan hasil belajar biologi siswa kelas X MIPA di SMAN Rambipuji Jember sebesar $12,2 \%$. Kemudian untuk koefesien determinasi $\left(\mathrm{r}^{2}\right)$ variabel minat belajar $\left(\mathrm{X}_{2}\right)$ yaitu 0,355 yang artinya sumbangan variabel $\left(\mathrm{X}_{2}\right)$ terhadap naik turunya variabel $(\mathrm{Y})$ sebesar $35,5 \%$ dimana variabel bebas lainnya tetap.

Secara simultan diketahui bahwa koefesien determinasi kecerdasan emosional dan minat belajar adalalah sebesar 0,513 yang berarti bahwa sumbangan kecerdasan emosional dan minat belajar terhadap naik turunya variabel Y adalah 51,3\%. Dengan kata lain dapat dijelaskan bahwa 51,3\% variasi naik turunya hasil belajar biologi siswa kelas X MIPA di SMAN Rambipuji Jember bisa diprediksikan oleh variabel kecerdasan emosional dan minat belajar. Dan 48,7\% dipengaruhi oleh faktor lain.

\section{PEMBAHASAN}

1. Pengaruh kecerdasan emosional dan minat belajar secara simultan dengan hasil belajar biologi siswa kelas X MIPA di SMAN Rambipuji Jember

Dalam penelitian ini digunakan untuk mengetahui pengaruh kecerdasan emosional dan minat belajar secara simultan dengan hasil belajar biologi kelas X MIPA di SMAN Rambipuji Jember. Setelah dilakukan analisis multivariet atau uji kolerasi ganda dangan statistik uji $\mathrm{F}$ terbukti bahwa hipotesis $\left(\mathrm{H}_{\mathrm{a}} 1\right)$ diterima, sehingga dapat dikatakan bahwa secara simultan kecerdasan emosional dan minat belajar berpengaruh signifikan terhadap hasil belajar biologi siswa kelas X MIPA di SMAN Rambipuji Jember. Hal ini berarti semakin tinggi kecerdasan emosional dan minat belajar secara simultan maka semakin tinggi hasil belajar biologi siswa, sedangkan semakin rendah kecerdasan emosional dan minat belajar secara simultan maka semakin rendah hasil belajar biologi siswa. 
Hasil Penelitian ini mendukung penelitian Nur (2020: 66) yang menunjukkan variabel minat dan variabel kecerdasan emosional berdampak positif secara bersama-sama terhadap hasil belajar matematika pada siswa kelas VII SMP Negeri 1 Sungguminasa dengan taraf signifikan $<0,05$ yaitu $(0,00<0,05)$ dan $F_{\text {hitung }} 38,434>F_{\text {tabel }} 3$. Begitu pula dengan penlitian yang dilakukan oleh Betris Juliana Situmorang pada tahun 2020 yang menyatakan pada uji koefisien determinasi nilai Adjusted R Square 0,609 membuktikan bahwa variabel bebas kecerdasan emosional $\left(\mathrm{X}_{1}\right)$, lingkungan kampus $\left(\mathrm{X}_{2}\right)$, dan penggunaan media sosial $\left(\mathrm{X}_{3}\right)$ secara bersama-sama mempengaruhi variabel terikat $(\mathrm{Y})$ sebesar $60,9 \%$, sedangkan sisanya sebesar 39,1\% dipengaruhi oleh variabel lain yang tidak termasuk dalam penelitian ini. Hasil Uji F membuktikan nilai sig $F$ hitung $<0,05$, maka dapat disimpulkan bahwa secara bersama-sama variabel $\left(\mathrm{X}_{1}\right),\left(\mathrm{X}_{2}\right),\left(\mathrm{X}_{3}\right)$, berpengaruh terhadap Y.

Sesuai dengan pendapat Purnama (2016: 234-235) untuk mencapai prestasi yang tinggi, selain kecerdasan, minat siswa juga diperlukan, sebab tanpa minat proses belajar mengajar berjalan kurang efektif. Kecerdasan emosional menjadikan diri siswa untuk bisa menerima kemampuannya, mengatur dirinya, memiliki empati dan kemampuan membina hubungan dengan guru maupun temannya di sekolah dengan baik. Sedangkan dengan adanya minat, siswa akan merasa tertarik untuk belajar biologi. Sebagai faktor psikologis, implementasi kecerdasan emosional dan minat membantu siswa untuk memahami dan menguasai konsep suatu mata pelajaran. Kecerdasan emosional dan minat memiliki pengaruh dengan penguasaan konsep suatu mata pelajaran (Sari, 2020: 45-46)

Dari hasil pembahasan diatas dapat disimpulkan bahwa siswa yang memiliki kecerdasan emosional dan minat belajar yang tinggi maka akan memiliki kemampuan yang baik dalam menyelesaikan permasalahan dalam pembelajaran biologi serta akan memiliki keingintahuan yang tinggi terhadap biologi sehingga akan memiliki hasil belajar biologi yang tinggi. Namun sebaliknya, jika siswa yang memiliki kecerdasan emosioanal dan minat belajar yang rendah maka akan kurang memiliki kemampuan dalam menyelesaikan permasalahan dalam pembelajaran biologi serta jika kurang memiliki keingintahuan rendah terhadap biologi maka akan memiliki hasil belajar yang rendah.

2. Pengaruh kecerdasan emosional dan minat belajar secara parsial dengan hasil belajar biologi siswa kelas X MIPA di SMAN Rambipuji Jember 
a. Pengaruh kecerdasan emosional terhadap hasil belajar biologi siswa kelas X MIPA di SMAN Rambipuji Jember.

Bedasar nilai uji statistik uji t diperoleh nilai $t_{\text {hitung }}>t_{\text {tabel }}(5,803>1983)$ dengan sig $=0.000$. karena nilai sig $0.00<0.05$ maka dapat dikatakan signifikan, hal ini menunjukan hipotesis ke lima diterima yang artinya ada pengaruh yang positif dan signifikan antara kecerdasan emosional terhadap hasil belajar siswa kelas X MIPA di SMAN Rambipuji Jember. Hal ini menunjukkan kecerdasan emosional berpengaruh terhadap naik turunnya hasil belajar siswa. Jika kecerdasan emosional tinggi maka hasil belajar biologi juga akan tinggi, sabaliknya jika kecerdasan emosional rendah maka hasil belajar juga rendah.

Penelitian yang dilakukan Arillo (2020: 123) yang berjudul "Pengaruh Kecerdasan Emosional dan Motivasi terhadap Hasil Belajar PPKN Kelas IV SD SeDabin I Kecamatan Margadana Kota Tegal”. Diketahui bahwa kecerdasan emosional memiliki pengaruh sebesar $10,7 \%$ terhadap hasil belajar PPKn siswa. Faktor yang memengaruhi hasil belajar siswa dibagi menjadi dua macam, yaitu faktor intern dan faktor ekstern. Dalam penelitian tersebut faktor yang diteliti adalah kecerdasan emosional dan termasuk ke dalam faktor intern.

Adanya pengaruh kecerdasan emosional terhadap hasil belajar sejalan dengan pendapat Banjarnahor (2020: 207) bahwa pada proses pembelajaran emosi sangat berpengaruh. Siswa mencapai keberhasilan disekolah bukan dilihat dari kumpulan fakta seseorang bisa membaca, melainkan dari ukuran emosi dan sosial. Pengelolaan kecerdasan emosional yang baik dapat menentukan keberhasilan siswa dalam membangun minat belajar yang tinggi dan dapat mengurangi perilaku agresif. Ketika siswa memiliki kecerdasan emosi yang baik ditandai dengan kemampuan mengenali emosi diri sendiri maupun orang lain, membina hubungan kerjasama yang baik, maka minat belajar juga semakin tinggi, dengan bertukar pikiran, saling berpendapat, memberikan banyak saran terhadap sesama teman menghasilkan banyak jawaban yang bervariasi di dalam menyelesaikan masalah yang mereka hadapi. Siswa lebih terlatih bahwa jalan menyelesaikan masalah harus dengan mengelola emosi dengan bantuan minat yang dimilikinya.

Dari hasil pembahasan diatas dapat disimpulkan bahwa siswa yang memiliki kecerdasan emosional yang tinggi maka akan memiliki kemampuan yang baik dalam 
menyelesaikan permasalahan dalam pembelajaran biologi sehingga akan memiliki hasil belajar biologi yang tinggi. Namun sebaliknya, jika siswa yang memiliki kecerdasan emosional yang rendah maka akan kurang memiliki kemampuan dalam menyelesaikan permasalahan dalam pembelajaran biologi maka akan memiliki hasil belajar yang rendah.

b. Pengaruh minat belajar terhadap hasil belajar biologi siswa kelas X MIPA di SMAN Rambipuji Jember.

Bedasar penilai uji statistik t diperoleh nilai $t_{\text {hitung }}>t_{\text {tabel }}(2,345>1,983)$ dengan sig $=0.05$. karena nilai sig $0.021<0.05$ maka dapat dikatakan signifikan, hal ini menunjukan hipotesis ke lima diterima yang artinya ada pengaruh yang positif dan signifikan antara minat belajar terhadap hasil belajar siswa kelas X MIPA di SMAN Rambipuji Jember.

Hasil Penelitian ini mendukung penelitian Sekar (2019: 126) menujukkan hasil data uji simultan (Uji F) menunjukkan bahwa skor dimana Fhitung $=66,936$ lebih besar dari Ftabel $=3,35$ atau $F_{\text {hitung }}=66,936>F_{\text {tabel }}=3,35$. Hasil Uji Parsial (Uji T) menunjukkan thitung sebesar 8,181 dengan nilai sig hitung 0,000 yang artinya uji t menunjukkan adanya pengaruh karena nilai sig hitung kurang dari 0,05.

Adanya pengaruh minat belajar terhadap hasil belajar sejalan dengan yang dikemukakan Aprijal (2020: 78) yaitu minat berkaitan dengan motivasi, karena minat merupakan dorongan dalam diri seseorang atau faktor yang menimbulkan perhatian secara selektif, yang menyebabkan dipilihnya suatu objek atau kegiatan yang menguntungkan, menyenangkan yang lama kelamaan akan mendatangkan kepuasan. Oleh karena itu antara dorongan, perhatian dan rasa senang pada suatu kegiatan saling berkaitan dengan faktor yang menimbulkan minat. Apabila faktor-faktor yang menimbulkan minat pada suatu kegiatan rendah maka dapat menyebabkan minat orang tersebut rendah. Minat yang rendah dapat menimbulkan rasa bosan terhadap suatu kegiatan. Apabila ini terjadi pada minat belajar, maka akan berdampak pada kesulitan belajar orang tersebut. Dalam hal ini, minat belajar siswa sangat berpengaruh terhadap hasil belajar siswa.

Dari hasil pembahasan diatas dapat disimpulkan bahwa siswa yang memiliki minat belajar yang tinggi maka akan memiliki kemampuan yang baik akan memiliki keingintahuan yang tinggi terhadap biologi sehingga akan memiliki hasil belajar 
biologi yang tinggi. Namun sebaliknya, jika siswa yang memiliki minat belajar yang rendah maka akan kurang memiliki keingintahuan terhadap biologi maka akan memiliki hasil belajar yang rendah.

Dari hasil tabulasi data kecerdasan emosional dan minat belajar terhadap hasil belajar biologi siswa yaitu dengan kecerdasan emosional sebesar 48,7\% dan minat belajar sebesar $35,5 \%$. Hal ini berarti masih terdapat faktor lain yang mempengaruhi hasil belajar sebesar $15,8 \%$. Dari kedua variabel tersebut menunjukkan masih ada yang perlu diperhatikan agar bisa memberikan hasil belajar yang maksimal dan berkualitas terhadap pembelajaran biologi.

\section{KESIMPULAN DAN SARAN}

\section{Kesimpulan}

Bedasarkan hasil dari penelitian dan analisis data serta pengujian hipotesis yang dilakukan di kelas X MIPA SMAN Rambipuji Jember, maka dapat disimpukan bahwa: pertama, Terdapat pengaruh langsung yang signifikan kecerdasan emosional dan minat belajar secara simultan terhadap hasil belajar biologi kelas X MIPA di SMAN Rambipuji Jember. Hal ini dibuktikan oleh hasil pengujian hipotesis melalui koefesien jalur variabel kecerdasan emosional dan minat belajar terhadap hasil belajar siswa dengan nilai $F_{\text {hitung }}>$ $F_{\text {tabel }}(54,722>3,08)$ dengan sig $=0.000$. karena nilai sig $0.000<0.05$ yang berarti terdapat pengaruh yang signifikan. Sesuai dengan uji koefesien determinasi $\left(R^{2}\right)$ yang diperoleh hasil 0,513. Hal ini menujukan kecerdasan emosional dan minat belajar secara simultan berpengaruh terhadap hasil belajar sebesar 51,3\% dan 48,7\% dipengaruhi faktor lain. Kedua, Terdapat pengaruh langsung yang signifikan kecerdasan emosional dan minat belajar secara parsial terhadap hasil belajar biologi kelas X MIPA di SMAN Rambipuji Jember. Hasil uji statistik t pada variabel kecerdasan emosional diperoleh nilai $t_{\text {hitung }}>t_{\text {tabel }}(2,345>1,983)$ dengan sig=0.05. karena nilai sig $0.021<0.05$ maka dapat dikatakan signifikan. Untuk uji statistik t pada variabel minat belajar diperoleh nilai $t_{\text {hitung }}>t_{\text {tabel }}(5,803>1983)$ dengan sig $=0.000$. karena nilai sig $0.02<0.05$ maka dapat dikatakan signifikan.

\section{Saran}

Berdasarkan hasil penelitian yang telah dilakukan maka terdapat beberapa saran diantaranya: Pertama, bagi guru diharapkan dapat lebih memahami karakter siswa dan dapat 
menggunakan metode, model yang bervariasi agar menambah minat dan hasil belajar biologi siswa. Kedua, bagi siswa agar dapat meningkatkan kualitas belajar dan dapat menumbuhkan kesadaran diri siswa bahwa siswa adalah subyek belajar bukan objek belajar, dan diharapkan siswa dapat aktif dalam proses pembelajaran. Ketiga, bagi peneliti selanjutnya diharapkan dapat mengembangan penelitian ini dengan sudut pandang yang berbeda.

\section{DAFTAR RUJUKAN}

Aprijal., Alfian, dan Syarifudin. "Pengaruh Minat Belajar Siswa Terhadap Hasil Belajar Siswa di Madrasah Ibtidaiyah Darussalam Sungai Salak Kecamatan Tempuling.” Jurnal Kependidikan MI 6. no. 1 (2020), 78.

Banjarnahor, Novia. "Hubungan Kecerdasan Emosional dengan Minat Belajar Siswa Kelas IV SDN 173418 Pollung.” School Education Journal, (2020). 207.

Berutu, Muhammad Hasyim Ansyar dan Tambunan Muhammad Iqbal H. "Pengaruh Minat dan Kebiasaan Belajar terhadap Hasil Belajar Biologi Siswa SMA Se-Kota Stabat.” Jurnal Bioslokus. No. 2 (2018), 108.

Darmayanti, Edita, Ferdinandus Etuasius Dole, Maria Kristina Ota. "Pengaruh Kecerdasan Emosional terhadap Kedisiplinan Belajar Peserta Didik di Sekolah Dasar." Jurnal Ilmiah Kependidikan, no. 1 (2021).

Ilmiyah, Nur Hafidhotul, dan Sumbawati Meini Sondang. "Pengaruh Media Kahoot dan Motivasi Belajar Terhadap Hasil Belajar Siswa." Journal Information Engineering and Educational Technology, no 1 (2019), 46.

Indria, Anita. Multiple Intelligence. Jurnal Kajian Dan Pengembangan Umat, no 1. (2020), 29.

Indriawati, Prita. "Pengaruh Kepercayaan Diri dan Kecerdasan Emosional terhadap Hasil Belajar Mahasiswa Universitas Balikpapan.” Jurnal Pendidikan Edutama: no. 2 (Juli 2018), 1.

Nesi, Mikael Dan Maik Akobiarek. "Pengaruh Minat dan Penggunaan Metode terhadap Hasil Belajar IPA Biologi Siswa Kelas VII SMP Negeri 2 Jayapura.” Bioedusains: Jurnal Pendidikan Biologi dan Sains, no 1 (Juni 2018), 81.

Puspita, Laila, Nanang Supriadi, dan Amanda Diah Pangestika. "Pengaruh Model Pembelajaran Creative Problem Solving (CPS) disertai Teknik Diagram Vee Terhadap Keterampilan Berpikir Kreatif Peserta Didik Materi Fungi Kelas X MAN 2 Bandar Lampung." Biosfer Jurnal Tadris Pendidikan Biologi, no. 2 (Agustus 2018), 2.

Qowiyah, Siti Halimatul. "Analisis Kecerdasan Interpersonal Anak Kelompok B”. Jurnal Pendidikan Anak Usia Dini, No. 2 (2020), 97.

Rohimah, Dya Fatkhiyatur, Blasius Suprapta, Dewa Agung Gede Agung. Pengaruh Model Pembelajaran Quantum Tipe Tandur terhadap Minat Belajar Siswa Kelas X. Jurnal 
Pendidikan, no. 9 (2019), 1229

Salsabilla, Sidqi dan Ashif Az Zafi. "Kecerdasan Interpersonal Peserta Didik Sekolah Dasar." Jurnal Pendidikan dan Pembelajaran Dasar. No 1 (2020)

Saputra, Hendra Dani, Ismet Faisal, dan Andrizal. "Motivasi terhadap Hasil Belajar Siswa SMK." Jurnal Inovasi Vokasional dan Teknologi, no. 1 (2018), 25.

Sari, Dewi Kurnia, Siti Suryaningsih, dan Luki Yunita. "mplementasi Kecerdasan Emosional dan Minat Siswa pada Pembelajaran Kimia." Jambura Journal of Educational Chemistry, no 1 (Juli 2019), 3.

Siregar, Lisnawati, Novi Fitriandika Sari, Risma Delima Harahap, dan Ika Chastanti. "Hubungan Kecerdasan Emosional terhadap Hasil Belajar Siswa pada Materi Pencemaran Lingkunga. Jurnal Pelita Pendidikan, no 2 (2019), 81.

Siregar, Syofian. Metode Penelitian Kuantitatif. Jakarta: Kencana. 2017.

Siyoto, Sandu dan Ali Sodik. Dasar Metodologi Penelitian. Yogyakaarta: Literasi Media Publishing, 2015.

Sugiono. Metode Penelitian Kuantitatif, Kualitatif, Dan R\&D. Bandung: Alfabeta, 2017.

Sulastyaningrum, Rizky, Trisno Martono, dan Budi Wahyono. "Pengaruh Kecerdasan Intelektual, Kecerdasan Emosional, dan Kecerdasan Spiritual terhadap Prestasi Belajar Mata Pelajaran Ekonomi pada Peserta Didik Kelas XI IPS di SMA Negeri 1 Bulu Tahun Ajaran 2017/2018." Jurnal Pendidikan Bisnis dan Ekonomi, no. 2 (2019), 3.

Zikra. "Analisis Faktor-Faktor Penyebab Kesulitan Belajar Biologi Siswa Kelas VII MTSS PGAI Padang. Bioconcetta, no. 2. (2016). 